\title{
KALDOR AND KORNAI ON ECONOMICS WITHOUT EQUILIBRIUM - TWO LIFE COURSES
}

\author{
Peter MIHALYI
}

Nicholas Kaldor and János Kornai are known in the academic literature as the most principled and unyielding opponents of the neoclassical, mainstream economics in general, and the Arrow-Debreu General Equilibrium Theory (GET) in particular since the beginning of the 1970s. Nevertheless, they remained in the minority camp with their views until today. The mainstream of the economic profession still holds that only the neoclassical paradigm offers a comprehensive, systematic, consistent and, above all, mathematical (hence "scientific") description of how modern economies operate. This paper aims at investigating why these two prolific writers, who were friends and spoke the same mother tongue, did not find a common ground and did not even try to build a school of followers jointly.

Keywords: equilibrium, increasing returns, demand constraint, perfect competition

JEL classification indices: B22, B31, D5, E12

Peter Mihalyi, Head of the Department of Macroeconomics, Corvinus University of Budapest, Hungary. E-mail: peter@mihalyi.com 
"The Anti-Equilibrium is not just one item on my publication list. This was the most ambitious enterprise of my entire career as a researcher." János Kornai (2007: 197)

"The challenge to equilibrium theory (...) will remain one of his most important legacies."

A. Philip Thirlwall (1987: 316)

\section{INTRODUCTION}

Is economics conceivable without the concept of equilibrium? In the 1983 Okun Lectures, three years before his untimely death, Nicholas Kaldor provocatively gave an affirmative answer to this question. Yes, economics is better off without equilibrium. This is not a minor issue for some specialists. "Economic theory based on the theory of general equilibrium have led to a 'cul de sac' which far from assisting the absorption of constantly accumulating knowledge and experience, has inhibited progress and thus created an important brake on the progressive development of economic thought" - he said elsewhere (Kaldor 1983c: 5). More than a decade earlier, János Kornai, choosing an even more provocative book-title, Anti-Equilibrium (AE for short), had given the same answer. In real life, economic actors - households, firms, or national economies - are never in a position, which can be meaningfully called "equilibrium"; they act under binding demand or resource constraints. Capitalist economies are inherently demandconstrained, while the socialist ones are resource-constrained. This is the takehome message of Kornai's several works since 1971. With their congruent views, nonetheless, these two great scholars remained in the minority camp until today. The mainstream of the economic profession still holds that only the neoclassical paradigm offers a comprehensive, systematic, consistent, and above all mathematical (hence "scientific") description of how modern economies operate.

"Wherever economics is used or thought about, equilibrium is a central organising idea" - this was the opening sentence of Frank Hahn's Inaugural lecture at Cambridge University in 1973. He, who certainly knew the works and the views of both Kaldor ${ }^{1}$ and Kornai very well at that point of time, did not want to say anything upsetting. He simply stated what was obvious for him and for the majority of his audience. In the lecture, he directly criticised Kaldor (1972) at great length, and then in a separate paper (Hahn 1973b) entirely devoted to the review of AE, he essentially rejected Kornai's standpoint as well. Interestingly, decades later Hahn was more permissive - but that was too late for Kaldor or for Kornai as 
an excuse or compensation. This is what Hahn said in a 2005 interview: "Kaldor of course was criticising very heavily people like me and so on for building castles in the air, or that we were making science fiction. There is something true in it, but at least we built something" (Basili - Zappia 2005: 17).

The cradle of the General Equilibrium Theory (GET) had been rocked by mathematicians and/or by theoretical economists with very strong inclination to think in mathematical models. This happened in the early 1950s, more than six decades ago. The key protagonists were Arrow and Debreu. What is less often considered is the biographical fact that in the year when the Arrow - Debreu (1954) paper was published by the American-born Kenneth J. Arrow, who taught economics at Stanford, and by the French-born mathematician, Gerard Debreu, who at that time worked at the Cowles Commission in Chicago, they were both 33 years of age. Both young men were at the beginning of the meteoric rise of their careers that culminated with the Nobel Memorial Prize in 1972 and 1983, respectively.

Among the founding fathers of GET, the name of Lionel McKenzie also needs to be mentioned. He was 35 years old, when his first major contribution (McKenzie 1954) was published, a month before the Arrow - Debreu (1954) paper. ${ }^{2}$ At the time, McKenzie was a student of the Dutch-American professor, Tjalling Koopmans, another GET icon, but his paper was to a large extent inspired by another Hungarian-born scholar, John von Neumann's German language manuscript, written in $1932 .^{3}$

Since the onset of the 2008 international financial crisis, the criticism of GET, the Dynamic Stochastic General Equilibrium (DSGE) modelling approach based on it, and in fact, the entire body of the neoclassical paradigm has become louder and more widely shared. ${ }^{4}$ In retrospect, it is also clear that strong declarations of the same nature had already been formulated a decade earlier by prominent representatives of the profession. Let us illustrate this claim with the examples of two Americans, whose words are quoted from a 530-page monograph entirely devoted to the criticism of Traditional Economics, as one author labelled the neoclassical synthesis (Beinhocker 2007). The first quote is from Joseph Stiglitz, the Nobel Prize winner of 2001, speaking publicly in the middle of the 1990s: "Any-

2 If we want to be very precise with the dates, it is worth mentioning that both the Arrow Debreu (1954) paper and the McKenzie (1954) paper had been publicly presented already at the Chicago Econometric Society meeting in December 1952. On the still sensitive issue of scientific priority between Arrow and Debreu on the one hand and McKenzie on the other, see Weintraub (2011).

For a detailed discussion of von Neumann's contribution to GET, see Zalai (2004).

See, e.g., the debates among experts within the European Union, succinctly summarised in Kirman's (2010) oft-cited paper. From the more recent assessments, see Blanchard (2016) and Krugman (2016). 
body looking at these models would say they can't provide a good description of the modern world" (p. 22). The second quote is from Alan Greenspan, writing in the early 2000s: "We really don't know how the economy works... The old models just are not working" (ibid.). In fact, this circle can be broadened. A thorough analysis of the Nobel Prize Lectures of all economists showed that 8 laureates - Hayek, Simon, Solow, Havelmo, Coase, North, Sen, and Kahneman - emphatically stated in their addresses that the neoclassical theory was actually wrong, in whole or in part, on either empirical or theoretical grounds. All of them said that the theory could not be true (Offer - Söderberg 2016: 65).

This paper does not intend to deliver justice to any of the schools, either the GET supporters or those who think that - using one of Kaldor's formulation - economic theory works better without the equilibrium approach. Our modest objective in the remaining part of the paper is to attempt to solve a small mystery. We shall try to show why these two prolific writers, Kaldor and Kornai, who were friends and spoke the same mother tongue did not find a common ground and did not even try to build a school of followers jointly. The other part of the question, namely why GET has remained practically an unchallenged concept for 99 per cent of lecturers teaching in economics departments until today, will not be touched upon in the present paper.

Before we start our comparative analysis, one important caveat seems in order. Almost everything that we shall quote from Kaldor or Kornai was formulated in the 1970 s and 1980 s as a critique of works authored in the 1950s. Since then, equilibrium models developed in several directions and some of the criticism expressed by our main protagonists has been already incorporated into the newer models (e.g. the role of government, taxation, fiscal and monetary policies).

\section{INTERACTIONS}

Kaldor and Kornai met in Cambridge in July 1963 on the occasion of a roundtable conference of the International Economic Association, where Kornai delivered a talk in German ${ }^{6}$ on long-term planning in Hungary - his main research

5 In this regard, it is worth quoting Kaldor's hardly known Joan Robinson Lecture, in which he touched upon the issue of timeliness in a very opinionated language: "the theory of general competitive equilibrium attained its present 'mature shape' by 1954; since then nothing of any importance, so I understand, has been added to it" Kaldor (1983c: 2).

6 At that time, Kornai still did not possess a sufficiently secure command of the English language. Interestingly, English was only the third language of all the great Hungarian-born economists mentioned in this paper, namely for Thomas Balogh, Nicholas Kaldor, Janos Kornai, John von Neumann, and Tibor Scitovsky (after Hungarian and German). 
topic at that time. When they met, Kornai also happened to be 33, like Arrow and Debreu when they authored the seminal paper of GET, though Kornai was somewhat older (39) when he completed the first draft of Anti-Equilibrium in 1967. The final version of AE, approximately twice as long as the $1967 \mathrm{draft}$, was published simultaneously in Hungarian and in English in 1971, when Kornai was already 43 .

Kaldor was almost a generation older, 55 years of age in 1963 . When they met for the first time, they were both already beyond a fundamental change in their worldview (Weltanschauung). Kornai used to be a Marxist; Kaldor had been trained on neoclassical models. But they fundamentally changed their way of thinking as they entered the fourth decade of their lives, as if they wanted to confirm Keynes's famous dictum on the very last page of The General Theory, that only very few people "can be influenced by new theories after they are twentyfive or thirty years of age" (op.cit.: 384) - most scholars never leave the doctrine they were trained in. But these two did. When they first met in Cambridge, Kornai must have already known the name of Nicholas Kaldor, as a prominent Hungarian-born economist living in England. Kaldor's name was well known in politically well-versed circles in Budapest after World War II, since Kaldor had helped the Hungarian Social Democratic Party with his economic advice for a short time. ${ }^{7}$ However, as far as we can establish from Kornai's entire oeuvre, he was not familiar with any of Kaldor's pre-1970 writings on the subject matter of the present paper.

This is not surprising. First, in the 1950s and 1960s, Kornai lived in Hungary, very far from the cross-border scholarly flows of information. Secondly, Kaldor's first papers attacking the neoclassical paradigm - apart from one exception, namely Kaldor (1966) - were all published in the later 1930s, when Kornai was still a child. Kaldor returned to this subject with full strength and firepower only after the publication of Anti-Equilibrium. In any case, Kaldor was not listed in the name index of the published version of $\mathrm{AE}$, and none of his writings were cited among the 286 references.

After their first personal encounter, Kaldor and Kornai remained close personal and family friends during the next 25 years. They frequently met in England and in Hungary, but they did not become comrades-in-arms in the bitterly competitive sports arena of the international scientific world in spite of the fact that the intellectual fight against GET was vitally important for both men.

The research and publication strategies of the two men were different. Kaldor never wrote a full-length book, most of his works, including the ones relevant

For a detailed analysis of Kaldor's activity in Hungary, see Mommen's (2017) paper in the present issue. 
Table 1. The most important publications of Kaldor and Kornai challenging GET

\begin{tabular}{|c|c|}
\hline Kaldor & Kornai \\
\hline $\begin{array}{l}\text { Marginal Productivity and Macroeconomic } \\
\text { Theories of Distribution (Polemics with } \\
\text { Samuelson and Modigliani, 1966) }\end{array}$ & $\begin{array}{l}\text { Anti-Equilibrium (An Essay), (1967 Hungarian, } \\
1968 \text { English) - Mimeo. }\end{array}$ \\
\hline $\begin{array}{l}\text { The Irrelevance of Equilibrium Economics } \\
\text { (Goodricke Lecture, May 1972) \# }\end{array}$ & Anti-Equilibrium (1971) \\
\hline $\begin{array}{l}\text { Equilibrium Theory and Growth Theory } \\
\text { (Barcelona lecture, April 1973) \# }\end{array}$ & Kornai - Martos (1973) \\
\hline $\begin{array}{l}\text { What is Wrong with Economic Theory } \\
\text { (Harvard lecture, April 1974) }\end{array}$ & $\begin{array}{l}\text { Resource-Constrained versus Demand- } \\
\text { Constrained Systems (1979) }\end{array}$ \\
\hline Limitations of the General Theory (1982) \# & Economics of Shortage $(1980)+$ \\
\hline $\begin{array}{l}\text { Economics without Equilibrium } \\
\text { (Okun Lectures, October 1983) \# }\end{array}$ & The Socialist System (1992) \\
\hline $\begin{array}{l}\text { The Futility of General Equilibrium Theory } \\
\text { (Joan Robinson Memorial Lecture at Harvard, } \\
\text { October 28, 1983) \# }\end{array}$ & $\begin{array}{l}\text { Against the Mainstream. Ch. } 10 \text { in By Force of } \\
\text { Thought (Irregular Memoirs of an Intellectual } \\
\text { Journey) (2007) }+\end{array}$ \\
\hline Recollections of an Economist (1986) \# & $\begin{array}{l}\text { Dynamism, Rivalry and the Surplus Economy } \\
(2014)+\end{array}$ \\
\hline
\end{tabular}

Notes: \# Reference to Kornai; + Reference to Kaldor.

for the present paper, came to light in the form of guest lectures and/or academic papers for scholarly journals. By contrast, Kornai's main form of self-expression was writing voluminous monographs, like Anti-Equilibrium itself, Economics of Shortage (1980), The Socialist System (1992), and his more recent book, Dynamism, Rivalry and the Surplus Economy (2014). Table 1 above gives an overview of the most important writings of the two authors from the perspective of our subject.

In AE, Kornai gave a list of 12 points in a tabulated form with detailed explanations (Table 2). In Kaldor's various writings, many of these points were discussed or at least mentioned at greater or shorter length, but never in such a systematic way. For example, in Kaldor (1934a), where the term "cobweb theorem" was first coined in the literature in the context of emphasising the importance of changing expectations in the prevention of reaching a static equilibrium of certain markets, the neoclassical theory was labelled exactly in the same way ("static theory"). The "lack of uncertainty" was criticised in Kaldor (1966). In Kornai's line of reasoning, the GET model's simplification to limit the actors to producers or consumers was contrary to everyday reality. Writing on the same issue, Kaldor discussed at length in many instances the importance of traders, middle men - rather than accepting the simple view according to which producers and consumers meet on markets in the form of "direct exchange" (first in Kaldor 1934a, later in Kaldor 1983c). 
Table 2. The "self-evident postulates" of GET according to Kornai

\begin{tabular}{l|l}
\hline 1 & Static/stationary character \\
\hline 2 & The set of organisations is given \\
\hline 3 & Agents: producers and consumers only \\
\hline 4 & Set of products is given \\
\hline 5 & Simultaneous operation \\
\hline 6 & Set of production is convex \\
\hline 7 & Profit maximisation \\
\hline 8 & Consumer utility maximisation \\
\hline 9 & $\begin{array}{l}\text { Set of production and consumption and preference ordering } \\
\text { are given }\end{array}$ \\
\hline 10 & Only price information provides incentives \\
\hline 11 & Anonymous relations on all markets \\
\hline 12 & Lack of uncertainty \\
\hline Source: Kornai (1971: Table 3.1).
\end{tabular}

Kaldor, as we already noted, never put together a monograph, in which all his criticism against GET can be found. In order to reconstruct his views, we had to assemble his " 12 point list" ourselves. ${ }^{8}$ As far as we can judge, there are only two points in Kornai's list (nos 4 and 10), where one can securely document that in his later works, Kaldor directly relied on Anti-Equilibrium and Kornai's underlying theoretical construct. It is particularly important to underline, as it was already shown in Table 1, that in many of his writings, Kaldor cited Kornai's most original assertion, namely that much regulation takes place in all market economies based on quantity signals, rather than on price signals, as the neoclassical model presupposes. ${ }^{9}$ In Kaldor (1983c) one can find a long paragraph, praising Kornai (1971) for his concept of "vegetative control" that helps greatly to understand how a rise or fall in inventories automatically and instantly activate reactions from producers even, if there are no price changes at that moment. On other,

$8 \quad$ The list by Thirlwall (1987: 319), Kaldor's biographer, is a good starting point. In Kaldor (1973), we found 7 such points listed.

9 Unfortunately, the correct references of Kaldor to Kornai's precedence in understanding the importance of quantity signals do not prevent the generation of young researchers to attribute this particular idea entirely to Kaldor, rather than to Kornai (see, e.g., Chappe 2016). Kornai had really bad luck with Arrow as well. While it is true that in his Nobel Prize lecture, Arrow (1972) cited Kornai's (1971) work in the main text on the very same point (notably the importance of quantity signals), his name and the bibliographic reference to it was left out of the reference list by mistake. True, the name of Kaldor was not even mentioned in the Nobel lecture. 
related issues, Kaldor's sporadic comments were formulated with a similar intention, but in a less precise way - if compared to AE.

In closing, it is important to underline that Kaldor's most elaborate and detailed acknowledgement of Kornai's achievements in questioning the fundamentals of GET was presented in the so-called Joan Robinson lecture at Harvard (Kaldor 1983c). Regrettably, this talk was not published subsequently - as was generally the case with similar lectures. ${ }^{10}$ In fact, the Robinson lecture is unique in the entire anti-equilibrium literature by acknowledging the importance of quantity signals in the Western-type, decentralised market economies. In the way Kaldor referred to and interpreted Kornai's ideas in AE, it is clear that he considered this approach as a possible avenue to develop an empirically testable microeconomic foundation for the Keynesian macro-model.

\section{TWO LIFE COURSES}

Kaldor started his economic education as a favourite student of Robbins and Hayek at the LSE in 1927. However, within a relatively short time, he became disillusioned with the neoclassical approach, or what his fellow Hungarian-born economist, Thomas Balogh later used to call "the restricted view" (Balogh 1982: 1). Shaping his mind, the then Head of the Economics Department, Allyn Young exerted the biggest impact on him. In Kaldor's own words, Young's (1928) paper convinced him that "the main function of markets is to transmit impulses to economic change, and thereby create more resources through enlarging the scope for specialisation and the division of labour - rather than to secure an optimum allocation of a given quantum of resources" (Kaldor 1978, italics in the original), as the traditional school claimed in line with the Walrasian approach. Subsequently, already as a member of the LSE faculty, he produced six essays between 1934 and 1938 on the determinateness of static equilibrium, the full implications of equilibrium for a model firm, the imperfect/monopolistic competition, and the notion of excess capacity. All this happened many years before the birth of the Arrow - Debreu (1954) paper.

Thus, Kaldor was intellectually relieved in 1949, when the opportunity came for him to move from the neoclassical world of LSE to Cambridge and resume the academic path after he had spent some years at the United Nations Economic

10 Most probably, the editors of Kaldor's collected works assumed that the Okun lectures, delivered at about the same time at Yale and reprinted two years later, contained everything that Kaldor had to say about "economics without equilibrium". The typewritten text of Kaldor's Robinson lecture has been preserved in the Kings' College Archive (Cambridge, UK). 
Commission in Geneva. Henceforth, he became a member of what Joan Robinson called the Cambridge Anglo-Italian school, where at least half of the Faculty of Economics were deeply sceptical about GET, the Samuelsonian synthesis of Keynesianism and the neoclassical tradition. Most of them went even further than Keynes himself in the search for a "dynamic theory of economics". ${ }^{11}$ As we already noted above, timewise Kaldor was the first to go public with a systematic critique of the use of the equilibrium concept. As compared to the pre-war decades, Kaldor's research has become much more policy oriented. He tried to find an answer to such "mundane" questions like why capitalist economies perform differently, what is wrong with the growth rate of the British economy, should Britain join the Common Market, etc. The neoclassical equilibrium approach and GET were too abstract to help him in all this.

János Kornai lived and worked exclusively in Hungary until he accepted the first longer teaching position at Princeton in 1972. During the years when he worked on AE, he was isolated from similar minded Western scholars. ${ }^{12} \mathrm{He}$ did have younger co-workers both from Hungary and other countries, but he was the helper and not the one who got (intellectual) help. In fact, the word "isolation" is an exaggeration. In 1968, Kornai spent four months with Arrow at Stanford and in 1970, a stipend allowed him to stay 6 months with Koopmans ${ }^{13}$ at Yale. Both giants read AE (Arrow the English translation of the 1967 draft $^{14}$, Koopmans the manuscript of the final version) and they both helped him generously with comments, corrections, and suggestions. In his memoir, Kornai (2007: 178) quoted Arrow's self-ironical remark on AE after reading it: "It will make a fine obelisk on the burial mound of the general equilibrium theory".

Similarly, to Kaldor, Kornai was not so much a model-builder. He was more interested in "mundane" research questions such as what is wrong with centralised planning systems? If they are plainly dysfunctional, how do they function at all? What is the reason of the endemic shortages? Why is the socialist planning system incapable of meeting the quality standards of Western market economies?

11 Kaldor's expression is quoted in Levi (1973: 206). Besides Kaldor, Joan Robinson was probably the most prolific critical writer on the subject of equilibrium among the Cambridge economists (see, e.g., Harris 2005).

12 Strangely enough, there is no documented evidence in Kornai's writings on the approximate date, when he started to work on the criticism of GET. What is certain: he did not have any publication on GET before 1967 - not even in Hungarian. Like the vast majority of his academic output, the 200-page long manuscript from 1967, which elaborated all the basic ideas of the book, had been drafted first in Hungarian and distributed in mimeo form.

13 Kornai was particularly impressed by two pieces among Tjalling Koopmans' writings: Koopmans (1957) and Koopmans - Montias (1971). In Kaldor (1972: 196-201), there is also a long section acknowledging the contributions of Koopmans to the equilibrium discussion.

14 See Kornai (1968). 
Why is the planned economy unable to produce world-shattering innovations? Like Kaldor, Kornai also thought that the equilibrium approach would not help him to answer these questions.

\section{SHARED CONCLUSIONS AND POINTS OF DISAGREEMENTS}

In one of Kaldor's many directly polemic writings, he used the following metaphor to characterise the misleading trick of the equilibrium approach. The assumptions of the neoclassical economists are promised to function like scaffolding that can be removed once the new building is ready. "In fact, these props are never removed; the removal of any one of a number of them - as, for example, allowing increasing returns or learning-by-doing - is sufficient to cause the whole structure to collapse like a pack of cards. It is high time that the brilliant minds of M.I.T. were set to evolve a system of non-Euclidean economics which starts from a non-perfect, non-profit-maximising economy where such abstractions are initially unnecessary" (Kaldor 1966, 1978: 83). This resonates closely with sentences from the final pages of AE: "Now is the time to begin the synthesis on bases that are broader than general equilibrium theory and more in agreements with facts. (...) An indefinitely long queue of wrong models will still not converge to a good model" (op. cit.: 376, 382).

Kornai had two strong metaphors in AE. According to the first one, GET is merely a thought experiment. The other cited metaphor was borrowed from Heisenberg, i.e. from the world of physics: "A closed system cannot be improved (...) it is a mathematical crystal" (op.cit.: Section 25.2). Kaldor must have liked both metaphors too, because he used them repeatedly in his later writings.

Beyond the above-quoted, commonly shared telling metaphors, the common understanding of Kaldor and Kornai pertaining to the shortcomings and the uselessness of GET can be summarised in 8 points.

1. Biology is better suited than physics as a reference model for economic theory. This conviction was later re-established in the Nobel lectures of such divergent personalities as Friedrich Hayek (1974) and Herbert Simon (1978) (Offer - Söderberg 2016: 61-62).

2. It is a mistake to search for a single point of weakness in GET. The problems are numerous and mutually intertwined. Kornai was quite explicit, when he identified 12 such points in AE.

3. Perfect competition is a myth. In a capitalist market economy, markets are oligopolistic; the majority of sellers set their own price. In other words, firms especially the large and very large firms that generate technical progress - are 
price makers. ${ }^{15}$ As for empirics, both Kaldor and Kornai relied on Galbraith's (1967) seminal work.

4. The most important feature of the capitalist system is its dynamic nature. This dynamism, in turn, is generated and driven by social and political forces, including the system-inherent ideologies. GET is an attempt to emasculate the system by assuming that (i) given exogenous variables are immutable in time; and (ii) only quantities and prices matter.

5. It is mistaken to assume that supply and demand curves represent unequivocally independent combinations. They mutually codetermine each other without crossing each other in one and only one equilibrium point. ${ }^{16}$

6. Increasing returns to scale is one of the most important drivers of economic development. This cannot be left out from the theory in the name of mathematical convenience and/or the assumption that it in real life is incompatible with perfect competition. ${ }^{17}$

7. Markets are never in Walrasian equilibrium, they always display asymmetry in one way or another. The capitalist economy is always demand-constrained.

8. According to the mainstream textbooks, when all markets are in equilibrium, this point is Pareto optimal for all economic agents at the micro-level and thus at macroeconomic level as well. By contrast, both Kaldor and Kornai stressed that at the micro-level, the adjustment process never stops. In addition, Kornai forcefully avows that the equilibrium position at the macro-level is system specific: excess supply in the capitalist system, excess demand (shortages) in the socialist system.

The regrettable fact is that Kaldor and Kornai did not have the opportunity

to work together in a common physical space ${ }^{18}$ and their personal encounters

15 It is noteworthy that the dual concept of price-taker $v s$. price-maker was first coined by another Hungarian-born economist, Tibor Scitovsky (1951), whose works were often quoted by both Kaldor and Kornai.

16 In Kaldor's oeuvre, this idea was first launched in the context of the Cobweb Theorem, as already mentioned. In this model, the quantity produced depends on the price anticipated at the time of the sale and where supply at time of the sale determines the actual market price (Kaldor 1934).

17 In a 1961 letter to Kaldor, Solow defended the disregard of increasing returns to scale with the following two arguments: "the assumption of constant returns to scale is convenient for two reasons: mathematically, because it simplifies calculation, economically because without it competition runs into difficulties and competitive systems are the easiest to deal with". Quoted by Thirlwall (1987: 320).

18 Actually, Kornai did receive an invitation to a permanent teaching position in Cambridge at the Faculty of Economics from Richard Stone in 1963, i.e. before writing AE. He rejected this magnificent opportunity precisely because a permanent position was on offer. Kornai did not want to emigrate. On this chapter of his life, see Kornai (2007). 
were not so frequent that they could easily exchange views on broad and complex issues of economic theory. Neither did the internet, blogs, e-mails, or Skype exist, which could have helped them in bridging the distance between Cambridge and Budapest. Thus, it is no wonder that in a large number of areas, our two heroes represented divergent views and most probably never had the chance to thoroughly debate them.

1. Kaldor (as well as Thomas Balogh) entirely rejected the concept of production function and the marginal productivity theory of distribution ${ }^{19}$ that is based on it. Kaldor's theoretical standpoint was quite clear on income distribution. Wages and profits are the result of country-level bargaining (chiefly because of the uniquely strong power of the British trade unions at that time); they are not determined by technology. Kornai has never directly questioned the model family of different production functions and the marginal productivity theory of distribution. His occasional comments were rather neutral towards these two crucial tenets of neoclassical, mainstream economics.

2. Kornai's criticism is centred on GET's two core concepts: preferences and utilities. Kaldor never really questioned their usefulness.

3. Kaldor, echoing Leontief's (1971) and Balogh's (1982) harsh sentences, had strong reservations vis-à-vis the irresponsible use of mathematics, or mathiness, as it is called today (Roamer 2015). Kornai respected and used mathematics as much as the circumstances allowed him.

4. Kaldor honestly believed that the "existing" capitalist system can be reformed, after which it would function better and in a more rightful way. ${ }^{20}$ In the framework of Kornai's system paradigm, the essential features of the capitalist market economy cannot be changed without losing some of its intrinsic positive characteristics. He had strong reservations vis-à-vis the naive reformers of both systems. In the eyes of Kornai, Kaldor was a naïve reformer by believing that "the assumption of ever greater powers of control by the State"21 and within this, wisely designed employment and income policies can eliminate unemployment and inequalities. For Kornai, a capitalist economy worthy to its name is always a surplus economy, with substantial, idle excess capacities; a large portion of unsold goods held in the form of output stock and a relatively large underutilised labour force.

5. Kaldor was a social democrat, a planning Keynesian ${ }^{22}$ and salaried adviser of British Labour Prime Ministers. Furthermore, he served as a United Na-

19 See, e.g., Kaldor's own Introduction to Kaldor (1960).

20 See the introductory study of Gabor Oblath to Kaldor (1989).

21 These are Kaldor's own words, quoted by Levi (1973: 208).

22 A term coined by Balogh (1983: 4). 
tions civil servant, and later as an economic advisor of several foreign governments. Kornai was a communist at the beginning of his career, but already became a liberal in 1956 . He never assumed any political or foreign advisory function later on. ${ }^{23}$ There is more behind this difference than simply personal taste or dissimilar political systems in which the two men worked. Kaldor had no problem with the existence of social welfare functions based on the mechanism of social compensation. If there is a welfare enhancing economic proposition, winners of the proposed change can always over-compensate the losers. Kornai did not accept this logic for a number of scholarly reasons (as explained at some length in Kornai 2002).

\section{UNEXPLOITED ISSUES FOR FUTURE RESEARCH}

As the communist shortage economies ceased to exist after 1990, and thus virtually all developed economies have become demand-constrained, a new situation emerged for theoretical economics and model building. In our opinion, there are several valuable points in the anti-equilibrium legacy of our two heroes that might lead to new insights in the understanding of decentralised systems based on private ownership.

As a student of Allyn Young, Kaldor was deeply convinced from the 1930s onwards that increasing returns arising from, inter alia, the indivisibility of many types of physical capital was essential only in the manufacturing sector. He believed that other sectors such as agriculture and the service sectors resembled more the textbook constant returns to scale model. This assertion is unlikely to hold in our times. Thus, it would be an interesting research subject, if anyone tried to quantify such differences, if they exist at all, in the primary, secondary, and tertiary sectors of the economy. On several occasions, but in Kaldor (1975a) with a strong emphasis, Kaldor opined that complementarity of $\mathrm{K}$ and $\mathrm{L}$ is more important than the substitution between $\mathrm{K}$ and $\mathrm{L}$, as the traditional neoclassical approach postulated. "(T)the concentration on the substitution aspect which makes 'pure' equilibrium theory so lifeless and motionless" (Kaldor 1975, 1989: 400-401). In our opinion, one of the shortcomings of developmental aid policies pursued in the second half of the $20^{\text {th }}$ century is rooted exactly here. The HarrodDomar model, for example, assumed that if a poor country lacks capital, this could be compensated by the use of extra amount of labour - which was abun-

23 Nevertheless, it would be misleading to believe that Kornai lived in the ivory tower of academy after 1956. E.g., he was a member of the Hungarian central bank's Monetary Council between 1998 and 2001. 
dant anyway. The Solow model is built on the same erroneous assumption, too. The real difficulty in accelerating the development of any country can perhaps be best illustrated by a metaphor proposed by an internationally barely known Hungarian economist, Ferenc Jánossy (1966). In his seminal book on growth theory, he stated that "machine is the teacher of the worker", by which he simply wanted to say that workers could learn turning only on a turning-lathe or, in a more general sense, the accumulation of human capital goes hand-in-hand with the accumulation of physical capital.

As already underscored in the previous section, the critique of the concept of the aggregate production function was a central issue for Kaldor throughout his academic life. In this context, it is important to note that Robert Solow (2015) recently acknowledged in a conference talk ${ }^{24}$ and later in a short article that "what we measure as wages and profits both contain an element of rent. (...) What happens to it now [in the automobile manufacturing companies of Detroit - P. M.] is not so much a matter of economic law. It depends on bargaining power, business attitudes and practices, social norms and public opinion." In other words, wages and profits are essentially social constructs; they are not determined by a given level of technology as the Cobb-Douglas function, the Solow model, and their later versions contend. This is exactly what Kaldor (and Ricardo before him) had said all along.

At the end of his life, Kaldor managed to find a succinct form of identifying the fundamental limitation of Keynes's General Theory - a point with which Kornai would probably have fully agreed with, although he himself never wrote anything critical against Keynes. In Kaldor (1983b), we can find the following line of argument: If production was to be constrained by demand - as the grand oeuvre claimed in 1936 - there must be excess capacity. But the notion of excess capacity is not consistent with perfect competition, i.e. with the Marshallian tradition with which Keynes himself showed solidarity throughout his life. With a little dose of exaggeration, we may say that under this criticism the Keynesian innovation - and the neoclassical micro+macro synthesis built upon it - is collapsing like a house of cards.

From the anti-equilibrium legacy of János Kornai, three building blocks seem to be underutilised at present. Firstly, his tertium non datur proposition should be mentioned. In the dimension of politics, there is no third way. Democracy and economic decentralisation are the two sides of the same coin; just as dictatorship and centralisation also go hand-in-hand most of the time in most of the countries. Secondly, Kornai has forcefully argued since the 1970s, and still does so in his most recent writings (Kornai 2014, 2016) that the dynamism of the capitalist

24 See the personal account of one participant, Milanovic (2015). 
economy is the result of inter-firm rivalry, which is not hampered at all by the oligopolistic nature of markets, as the textbook version of the GET conveys to students. The absence of perfect completion is not damaging, but rather virtuous for technical progress. It allows the most efficient firms - not only in manufacturing, but also in the service sector - to harness higher-than-average profits through arbitrarily large mark-ups, or using a different terminology: exploiting a scarcity rent (Mihalyi - Szelényi 2016). Usually there are two interrelated factors behind this: pioneering technology and economy of scale arising from the concentration of firms at the national or the international level (e.g. through mergers and acquisitions). In fact, both of these factors play a crucial role in generating revolutionary (Schumpeterian) innovations. While this generalisation may sound idiosyncratic for many economists raised on neoclassical equilibrium models, it is a commonplace in the management science literature to say that many important industries never have more than three significant competitors. ${ }^{25}$ The same trend in the literature also claims that in many markets the shares of the three leading companies reach a ratio of approximately $4: 2: 1$, i.e. there is a significant market share difference even among the top firms. Data from US Census Bureau also supports this claim. In 2012, the top four US firms' average share of total revenue on a sector-by-sector basis was close to $50 \%$ in IT, telecoms and media sector, $40 \%$ in retail trade, and almost $40 \%$ in the finance and insurance sector. ${ }^{26}$

In our view, the third enormously valuable, but still underutilised proposition of Kornai is the partition of decisions of economic agents into two sub-groups. This idea was already present in $\mathrm{AE},{ }^{27}$ but Kornai returned to it many times later, including in his memoirs where he adapted his idea to analyse many of his personal decisions. In the GET model, all decisions are motivated by the same driving force and their implementations are all similar. Producers are maximising profits, consumers maximise their utilities. Both groups of actors are characterised by perfect foresight and lack of uncertainty. In contrast, Kornai contends that human decision-making is inherently different when it comes to recurrent and comparable choices on the one hand, and non-recurring and non-comparable choices on the other. In fact, it is trivial to agree on this distinction.

Quite clearly, when housewives do their daily shopping in a fruit market, they routinely compare prices and qualities before they buy apples from a particular

25 This finding was first demonstrated by the founder of the Boston Consulting Group, Bruce Henderson (1976), and then later re-confirmed empirically on a much larger data set by Reeves et al. (2012). Since then, successful companies such as General Electric and others live according to this maxim. If they cannot become Number One or Two in an industry, they get out from that market and reinvest their resources elsewhere.

26 The Economist, March 26, 2016.

27 See Section 10.4 
vendor. The situation is similar on the stock market, where brokers buy identical "goods" (shares, bonds, foreign currencies, etc.) from other traders. Therefore, in such transactions, it is only the price of the particular asset that counts. Every actor is a price-taker. To a large extent, this is the way that large manufacturing firms functioned in the first half of the $20^{\text {th }}$ century. Workers along the conveyor belt were easily replaceable - one worker was just as good as the other - therefore, it was once again only their price (i.e. their wage) what mattered. The decision-making model of GET is an accurate description of these types of routine decisions. With or without the Walrasian auctioneer, the choices are simple and almost instantaneous.

On the other hand, the process of decision-making is entirely different when non-recurring, irrevocable decisions are made in private life or in business. When people make choices of buying cars in every third or fourth year, deciding to purchase a house once or twice in their life, or choose a lifetime marriage partner, make a decision on having children, they are driven by considerations which are very far from the homo oeconomicus model underlying GET. The same holds in business. Large, business-critical investment decisions like building a new plant, merging with a major industrial competitor, or investing millions of dollars in a new innovation are never based on price information alone, as the representatives of GET contend in their argumentation. ${ }^{28}$ Many decades after AE, this differentiation between recurring and non-recurring decisions has become a triviality as a result of the well-publicised results of experimental psychology (Kahneman 2011), where already the title of the book underscored the same, fundamental difference: Thinking Fast and Slow.

\section{CONCLUSION}

In April 1973, Kaldor opened his lecture at the University of Barcelona with the following statement: "My purpose is to explain why I regard prevailing economic theories, as taught in the regular textbooks in most universities of the Western

\footnotetext{
28 A version of this argument was already used by Kaldor in the paper written against Samuelson and Modigliani. The issue debated was the alleged relentless pursuit of the principle of substitution. In the spirit of GET, Kaldor for a moment accepted that in the long run, the non-profit maximisers would fall by the wayside as a result of competition. In the next step, however, he rejected this argument by saying that "in a world of imperfect foresight and changing technology, the Darwinian process may favour the successful innovator who operates on hunches rather than the homo oeconomicus of the more pedestrian type, the careful equator of marginal substitution ratios" Kaldor (1966, 1978: 83). Without directly referencing, Kaldor used the "animal spirit" argumentation of Keynes in the General Theory (Ch. 12: The State of Long Term Expectations).
} 
World, as thoroughly misleading and pretty useless" (op.cit.: 273, my italics). This is exactly the position Kornai has recently formulated in his memoirs, with a certain amount of self-criticism. "It was a mistake to criticise the purity of the theory. The neoclassical school should have been targeted. The right addresses of my criticism should have been the teaching practice and the research program of mainstream economics" (Kornai 2007: 184-185).

It is probably not an exaggeration to say that Kaldor and Kornai became known in the English-speaking scholarly literature as the most significant antagonists of GET, while it is also true that they both failed - as well as many others - to shepherd the majority of the economic profession into the anti-equilibrium camp. Kaldor, like Thomas Balogh and Joan Robinson, with whom he was on a common wavelength as far as GET was concerned, used to communicate in a polemic and outspoken style both in their writings and oral presentations. They all fought particularly harshly with the American hegemony in economic theory. By contrast, Kornai was more inclusive and pedantically precise in giving credit to other authors for any useful points. But this difference did not matter much - Kaldor and Kornai achieved much less than they aspired to. As the years passed, their works have been slowly forgotten and the young, upcoming generation of economists does not encounter their names in the general curriculum of MA or PhD programmes. Sadly, it is not fashionable today to read books or papers written 50 or 80 years ago. Is this going to change in the upcoming decades?

\section{REFERENCES}

Arrow, K. J. (1972): General Economic Equilibrium: Purpose, Analytic Techniques, Collective Choice. Nobel Memorial Lecture, December 12. http://www.nobelprize.org/nobel_prizes/economic-sciences/laureates/1972/arrow-lecture.pdf

Arrow, K. J. - Debreu, G. (1954): Existence of an Equilibrium for a Competitive Economy. Econometrica, 22(3): 265-290.

Balogh, T. (1982): The Irrelevance of Conventional Economics. London: Weidenfeld and Nicolson.

Basili, M. - Zappia, C. (2005): An Interview with Frank Hahn on the Occasion of his 80th Birthday. Storia del Pensiero Economico, No. 2. http://www.econ-pol.unisi.it/zappia/interviewHahn.pdf

Beinhocker, E. D. (2007): The Origin of Wealth. Evolution, Complexity and the Radical Remaking of Economics. London: Random House Business Books.

Blanchard, O. (2016): Do DSGE Models Have a Future? Peterson Institute for International Economics, Working Paper, PB16-11. https://piie.com/system/files/documents/pb16-11.pdf, August.

Chappe, R. (2016): General Equilibrium Theory: Sound and Fury, Signifying Nothing? Institute for New Economic Thinking. Manuscript. https://www.ineteconomics.org/ideas-papers/blog/ general-equilibrium-theory-sound-and-fury-signifying-nothing

Debreu, G. (1959): Theory of Value. New York: Wiley \& Sons. 
Felipe, J. - McCombie, J. S. L. (2013): The Aggregate Production Function and the Measurement of Technical Change (Not even Wrong). Cheltenham: Edward Elgar.

Galbraith, J. K. (1967): The New Industrial State. Boston: Houghton - Mifflin.

Hahn, F. (1973a): On the Notion of Equilibrium in Economics (Inaugural Lecture). Cambridge University, 28 February.

Hahn, F. (1973b): The Winter of Our Discontent. Economica, New Series, 40(159): 322-330.

Harris, D. J. (2005): Robinson on 'History versus Equilibrium'. In: Gibson, B. (ed.): Joan Robinson's Economics. A Centennial Celebration. Cheltenham: Edward Elgar. pp.

Henderson, B. (1976): The Rule of Three and Four, https,//www.bcgperspectives.com/content/ Classics/strategy_the_rule_of_three_and_four/

Jánossy, F. (1966, 1971): The End of the Economic Miracle: Appearance and Reality in Economic Development. White Plains, NY: International Arts and Sciences Press.

Kahneman, D. (2011): Thinking, Fast and Slow. New York: Farrar, Straus and Giroux.

Kaldor, N. (1934a, 1960): A Classificatory Note on the Determinateness of Equilibrium. In: Essays on Value and Distribution. London: Gerald Duckworth \& Co. Ltd., pp. 13-33.

Kaldor, N. (1934b, 1960): The Equilibrium of the Firm. In: Essays on Value and Distribution. London: Gerald Duckworth \& Co. Ltd., pp. 34-50.

Kaldor, N. (1935, 1960): Market Imperfection and Excess Capacity. In: Essays on Value and Distribution. London: Gerald Duckworth \& Co. Ltd., pp. 62-80.

Kaldor, N. (1938, 1960): Professor Chamberlin on Monopolistic and Imperfect Competition. In: Essays on Value and Distribution. London: Gerald Duckworth \& Co. Ltd., pp. 81-95.

Kaldor, N. (1960): Introduction. In: Essays on Value and Distribution. London: Gerald Duckworth \& Co. Ltd., pp. 3-12.

Kaldor, N. (1966, 1978): Marginal Productivity and Macroeconomic Theories of Distribution. Comment on Samuelson and Modigliani. In: Further Essays in Economic Theory. London: Duckworth, pp. 81-99.

Kaldor, N. (1972, 1978): The Irrelevance of Equilibrium Economics (Goodricke Lecture at the University of New York, May 10). In: Further Essays in Economic Theory. London: Duckworth, pp. 176-201.

Kaldor, N. (1973, 1979): Equilibrium Theory and Growth (Lecture presented at the University of Barcelona, April 1973). In: Boskin, M. J. (ed.): Economics and Human Welfare. Essays in Honour of Tibor Scitovsky. New York: Academic Press, pp. 273-291.

Kaldor, N. (1974, 1979): What is Wrong with Economic Theory. Harvard University Political Economy Lecture, April 29. In: Further Essays in Economic Theory. London: Duckworth, pp. 202-213.

Kaldor, N. (1982, 1989): Limitations of the General Theory. In: Further Essays on Economic Theory and Policy. London: Duckworth, pp. 74-89.

Kaldor, N. (1983a, 1985): Economics without Equilibrium. Okun Lectures. Armonk, N.Y.: M.E. Sharpe, Inc.

Kaldor, N. (1983b): Keynesian Economics after Fifty Years. In: Worswick, D. - J. Trevithick, J. (eds): Keynes and the Modern World. Cambridge: Cambridge University Press, pp. 1-28.

Kaldor, N. (1983c): The Futility of General Equilibrium Theory (Joan Robinson Memorial Lecture at Harvard) October 28. Manuscript. King's College Archive, NK/2/139/22.

Kaldor, N. (1986, 1989): Recollections of an Economist. In: Further Essays on Economic Theory and Policy. London: Duckworth, pp. 13-40.

Kaldor, N. (1989): Gazdaságelmélet-gazdaságpolitika (Selected Essays on Economic Theory and Policy). In Hungarian: Oblath, G. (ed.). Budapest: KJK. 
Keynes, J. M. (1936, 1964): The General Theory of Employment, Interest, and Money. New YorkLondon: Harcourt Brace Jovanovich.

King, J. E. (2009): Nicholas Kaldor. Palgrave - Macmillan.

Kirman, A. (2012): What's the Use of Economics? Vox, 29 October. http://www.voxeu.org/article/ what-s-use-economics

Koopmans, T. C. (1957): Three Essays on the State of Economic Science. New York: McGrawHill.

Koopmans, T. C. - Montias, J. M. (1971): On the Description and Comparison of Economic Systems. Cowles Foundation Paper, No. 357.

Kornai, J. (1967): Anti-equilibrium. Esszé a gazdasági mechanizmus elméleteiről és a kutatás feladatairól (Anti-Equilibrium. On Economic Systems Theory and the Tasks of Research). Manuscript (in Hungarian). Budapest: Institue of Economics, Hungarian Academy of Sciences.

Kornai, J. (1968): Anti-Equilibrium. Manuscript. Budapest: Institue of Economics, Hungarian Academy of Sciences.

Kornai, J. (1971): Economic Systems Theory and General Equilibrium Theory. Acta Oeconomica, 6(4): 297-317.

Kornai, J. (1971): Anti-Equilibrium (On Economic Systems Theory and the Tasks of Research). Amsterdam: North-Holland.

Kornai, J. (1979): Resource-Constrained versus Demand-Constrained Systems. Econometrica, 47(4): 801-819.

Kornai, J. (1980): Economics of Shortage. Vol. A-B. Amsterdam: North-Holland.

Kornai, J. (1992): The Socialist System. The Political Economy of Communism. Oxford: Clarendon Press.

Kornai, J. (2002): A Joyful Economist: Tibor Scitovsky (1910-2002). The Hungarian Quarterly, 43(167): 136-139.

Kornai, J. (2007): By Force of Thought (Irregular Memoirs of an Intellectual Journey). Cambridge (MA): MIT Press.

Kornai, J. (2014): Dynamism, Rivalry and the Surplus Economy. Oxford: Oxford University Press.

Kornai, J. (2016): The System Paradigm Revisited. Clarifications and Additions in the Light of Experiences in the Post-Socialist Region. Acta Oeconomica, 66(4): 555-604.

Kornai, J. - Martos, B. (1973): Autonomous Control of the Economic System. Econometrica, 41(3): 509-528.

Krugman, P. (2016): The State of Macro is Sad (Wonkish). The New York Times, 12 August. http:// krugman.blogs.nytimes.com/2016/08/12/the-state-of-macro-is-sad-wonkish/?_r=0

Leontief, W. (1971): Theoretical Assumptions and Non-Observed Facts. American Economic Review, 61(1): 1-7.

Levi, A. (1973): Journey among the Economists. London: Alcove Press.

McKenzie, L. W. (1954): On Equilibrium in Graham's Model of World Trade and Other Competitive Systems. Econometrica, 22(2): 147-161.

McKenzie, L. W. (1959): On the Existence of General Equilibrium for a Competitive Economy. Econometrica, 27: 54-71.

Mihalyi, P. (2013): János Kornai's Anti-Equilibrium, a Harbinger of Evolutionary Economics. Acta Oeconomica, 63(3): 367-375; Reprinted In: Hámori, B. - Rosta, M. (eds) (2016): Constraints and Driving Forces in Economic Systems. Studies in Honour of János Kornai. Newcastle upon Tyne: Cambridge Scholars Publishing, pp. 77-86.

Mihalyi, P. - Szelényi, I. (2016): Two Different Sources of Inequalities: Profits and Rents in Advanced Market Economies. Institute of Economics, Centre for Economic and Regional Studies, Hungarian Academy of Sciences, Discussion Papers, MT-DP - 2016/30. 
Milanovic, B. (2015): Bob Solow on Rents and Decoupling of Productivity and Wages. Economist's View, 2 May. http://glineq.blogspot.hu/2015/05/bob-solow-on-rents-and-decoupling-of.html

Mommen, A. (2017): Káldor's versus Varga's - The Hungarian Three-Year Economic Reconstruction Plan of 1947. Acta Oeconomica, 67(Special Issue): 157-173.

Nell, E. J. - Semmler, W. (eds) (1991): Nicholas Kaldor and Mainstream Economics (Confrontation or Convergence). London: Macmillan.

Neumann von, J. (1945): A Model of General Economic Equilibrium. Review of Economic Studies, 13: $1-9$.

Offer, A. - Söderberg, G. (2016): The Nobel Factor. The Prize in Economics, Social Democracy, and the Market Turn. Princeton and Oxford: Oxford University Press.

Reeves, M. - Deimler, M. - Stalk, G. - Scognamiglio Pasini, F. L. (2012): BCG Classics Revisited. The Rule of Three and Four. BCG's Strategy Institute, https://www.bcgperspectives.com/content/articles/business_unit_strategy_the_rule_of_three_and_four_bcg_classics_revisited/

Romer, P. M. (2015): Mathiness in the Theory of Economic Growth. American Economic Review: Papers \& Proceedings, 105(5): 89-93.

Scitovsky, T. (1951): Welfare and Competition. London: Allen \& Unwin.

Simpson, D. (2013): Rediscovery of Classical Economics. Adaptation, Complexity and Growth. Cheltenham: Edward Elgar.

Solow, R. (2015): The Future of Work, Why Wages Aren't Keeping up? Pacific Standard, 11 August.

Targetti, F. (1992): Nicholas Kaldor. (The Economics and Politics of Capitalism as a Dynamic System). Oxford: Clarendon Press.

Thirlwall, A. P. (1987): Nicholas Kaldor. Brighton: Wheatsheaf Books.

Turner, M. S. (1993): Nicholas Kaldor and the Real World. Amon - London: M.E. Sharpe.

Weintraub, E. R. (2011): Lionel W. McKenzie and the Proof of the Existence of a Competitive Equilibrium. Journal of Economic Perspectives, 25(2): 199-215.

Zalai, E. (2004): The von Neumann Model and the Early Models of General Equilibrium. Acta Oeconomica, 54(1): 3-38. 